Evidence of Resource Procurement and Manufacturing Techniques in Caddoan Ceramic Assemblages from the Sabine, Cypress, and Sulphur River Drainage Basins, Rusk and Titus Counties, Texas

Kathryn Reese-Taylor Unknown

Follow this and additional works at: https://scholarworks.sfasu.edu/ita

Part of the American Material Culture Commons, Archaeological Anthropology Commons, Environmental Studies Commons, Other American Studies Commons, Other Arts and Humanities Commons, Other History of Art, Architecture, and Archaeology Commons, and the United States History Commons

Tell us how this article helped you.

This Article is brought to you for free and open access by the Center for Regional Heritage Research at SFA ScholarWorks. It has been accepted for inclusion in Index of Texas Archaeology: Open Access Gray Literature from the Lone Star State by an authorized editor of SFA ScholarWorks. For more information, please contact cdsscholarworks@sfasu.edu. 
Evidence of Resource Procurement and Manufacturing Techniques in Caddoan Ceramic Assemblages from the Sabine, Cypress, and Sulphur River Drainage Basins, Rusk and Titus Counties, Texas

Creative Commons License

(c) $(1)$ ( 8

This work is licensed under a Creative Commons Attribution-NonCommercial 4.0 International License 


\title{
EVIDENCE OF RESOURCE PROCUREMENT AND MANUFACTURING TECHNIQUES IN CADDOAN CERAMIC ASSEMBLAGES FROM THE SABINE, CYPRESS, AND SULPHUR RIVER DRAINAGE BASINS, RUSK AND TITUS COUNTIES, TEXAS
}

\author{
Kathyrn Reese-Taylor
}

\section{INTRODUCTION}

Texas Utilities Services and Espey, Huston \& Associates, Inc. have conducted ongoing archaeological investigations of cultural resources in Northeast Texas for the past 15 years. As a part of these studies, prehistoric Caddoan ceramic assemblages were recovered from 13 sites in three distinct drainage basins: three sites from the Sabine River drainage; three sites from the Cypress Creek drainage; and seven sites from the Sulphur River drainage. Recent research on the ceramic collections has emphasized variability in surface treatment, vessel form, and paste composition by means of a detailed attribute analysis and petrographic examination of a sample of the Caddoan sherds.

This paper focuses on the paste composition of a sherd sample selected to undergo petrographic analysis. The sample contains representatives among the sherds of the major tempering agents identified during a macroscopic examination of the pastes. The initial goal of the analyses was establishment of a baseline for paste composition in the study areas. A detailed point count, and grain size measurements, allowed for the identification of constituents in a range of frequencies from among the sites located in each of the three drainage basins. Upon completion of the initial studies, the results of the analyses from the three studies were compared. This paper presents a discussion of preliminary patterns identified in Caddoan ceramic assemblages of resource procurement and manufacturing techniques observed among the site samples. 


\section{SITE DESCRIPTIONS}

\section{Sabine River Drainage}

Three sites (41RK214, 41RK215, and 41RK216) are located on a north-south interfluve overlooking the floodplain of Mill Creek within the Sabine River drainage basin. Site 41RK214 (the Oak Hill Village) lies about 400 meters east of the main channel of Mill Creek. From the testing and recently completed excavations, the Oak Hill Village site is a large village with over 39 identified structures (see Rogers et al. 1994; Cruse 1995; Brett Cruse, 1995 personal communication). Preliminary analysis of the ceramics from the test excavations suggests a Middle Caddoan period occupation dating between ca. A.D. 1200 and A.D. 1400 (Rogers et al. 1994). This temporal designation coincides with a single radiocarbon date from the test excavations of A.D. 1230-1390 (calibrated date at two standard deviations).

Site 41RK215 sits adjacent to, and west of, the Oak Hill Village site, and lies 125 meters east of the main channel of Mill Creek. Typological identifications of the diagnostic ceramics also suggest that it was occupied during the Middle Caddoan period (see Rogers et al. 1994).

Site 41RK216 also lies west of the Oak Hill Village site, and the main channel of Mill Creek is approximately 150 meters west of the site. The relatively few diagnostic Caddoan ceramics recovered from the site in test excavations suggest it was occupied from ca. A.D. 1000-1400 (Rogers et al. 1994).

\section{Cypress Creek Drainage}

Sites 41TT370, 41TT372, and 41TT550 are located within the Cypress Creek drainage basin (Kotter et al. 1993). Site 41TT370 is situated on a small ridge approximately 60 meters west of Tankersley Creek. No clear cultural component can be associated with

the ceramics, other than they appear to be Caddoan in affiliation. Site 41TT372 is located east of the main branch of Tankersley Creek on a ridge complex bounded by spring-fed 
creek tributaries. An Early Caddoan period component (ca. A.D. 1000-1200) is postulated for the Caddoan occupation of the site (Reese-Taylor 1993). Finally, site 41TT550 covers an extensive ridge above the confluence of two headwater branches of Hayes Creek. The Caddoan component is a Late Caddoan period (ca. A.D. 1400-1680) period cemetery. The ceramics included in the present study were recovered during test excavations at the site (Kotter et al. 1993; Reese-Taylor 1993).

\section{Sulphur River Drainage}

Seven sites lie within the Sulphur River drainage, specifically along Piney Creek, a southern tributary of White Oak Creek (Nash et al. 1995). Ceramics from sites 41 TT392 and 41TT406 indicate they were occupied prior to A.D. 1200, while ceramics from sites 41TT396, 41TT399, 41TT400, and 41TT409 suggest they were used by Caddoan groups between about A.D. 1200-1680. The temporal affiliation of site 41TT601 was not conclusively determined during test excavations (Reese-Taylor 1995).

\section{METHODOLOGY}

\section{Point Count}

The sherd specimens were first submitted to have thin section slides prepared. One sample per slide was mounted using a blue epoxy resin for consolidation. The samples were then ground to the recommended thickness of $0.03 \mathrm{~mm}$ (Shepard 1976).

Initially, a scan of the thin section was completed at an objective of $4 \mathrm{X}$, and a description of the general characteristics of the clay matrix and the inclusions was recorded. Then, in order to quantify the data for statistical comparisons, a point count was taken at an objective of $10 \mathrm{X}$.

At least 200 points were counted, a number that has been determined to statistically represent all elements present in a sherd thin section sample (Rice 1987; Reese 1989). An interval was selected that was slightly larger than the average grain size for each specimen 
in order to avoid counting inclusions more than once. Then a point point which completely covered the thin section was conducted.

\section{Grain Size Count}

Grain size was determined by measuring 50 percent of the non-plastic inclusions at their maximum width. The grain size count was conducted in a similar fashion to the previously described point count.

The general shapes of the inclusions in the samples are based upon categories of roundness and sphericity established by AMSTRAT, the American/Canadian Stratigraphic Association (Folk 1968). Grain size characteristics were identified based upon the range, distribution, mode, and mean of each sample in relationship to the Wentworth Size Scale (Table 1). For the purposes of this study, naturally occurring inclusions are defined as inclusions falling within or below the class of Very Fine Sand $(0.125 \mathrm{~mm})$ on the Wentworth scale.

\section{DISCUSSION}

General paste categories were defined based upon the frequency of the clay, pores, and mineral inclusions identified during the point count. Further refinement of the paste classification were based upon grain size and shape attributes identified during the grain size count. Within the sample, seven paste classes were identified: sandy pastes, sandtempered, clay-grit-tempered, grog-tempered, grog- and bone-tempered, bone-tempered, and shell-tempered. However, the presence or absence of specific paste classes within the three drainage basins did not provide sensitive markers of similarities or differences among the samples. Therefore, for comparative purposes, the interpretation of the database produced by the point count and grain size measurements focused on: (1) the frequencies of various inclusions as indicators of resource procurement, and (2) the proportions of nonplastics and pores in relationship to each other as indicators of manufacturing techniques. 
Table 1.

Grain Size Scales for Sediments

\begin{tabular}{lll}
\hline Millimeters & Wentworth Size Class & Macro-Size Class \\
\hline$>256 \mathrm{~mm}$ & Boulder & \\
$64-256 \mathrm{~mm}$ & Cobble & Gravel \\
$4-64 \mathrm{~mm}$ & Pebble & \\
$2-4 \mathrm{~mm}$ & Granule & \\
\hline $1-2 \mathrm{~mm}$ & Very Coarse Sand & Sand \\
$0.5-1 \mathrm{~mm}$ & Coarse Sand & \\
$0.25-0.5 \mathrm{~mm}$ & Medium Sand & \\
$0.125-0.25 \mathrm{~mm}$ & Fine Sand & \\
$0.0625-0.125 \mathrm{~mm}$ & Very Fine Sand & \\
\hline $0.031-0.0625 \mathrm{~mm}$ & Coarse Silt & \\
$0.0156-0.031 \mathrm{~mm}$ & Medium Silt & \\
$0.0078-0.0156 \mathrm{~mm}$ & Fine Silt & \\
$0.0039-0.0078 \mathrm{~mm}$ & Very Fine Silt & \\
$<0.0039 \mathrm{~mm}$ & Clay & \\
\hline
\end{tabular}

\section{Resource Procurement}

In the present Caddoan ceramic assemblage samples, sands are indicated for the sources of the quartz and alkali feldspars because of the small size and the rounded to subrounded shape of the grains. All feldspars deteriorate in sedimentary sources at a faster rate than quartz; therefore, the frequency of alkali feldspars in sands is evidence of the relative maturity of the sand. The presence of alkali feldspars in frequencies over 25 percent 
suggests an immature sand or sandstone (graywacke); in frequencies between 10-25 percent, an immature arkosic sand or sandstone is indicated; while a mature quartz sand or sandstone is suggested with alkali feldspar frequencies less than 10 percent.

With rare exception, the presence of alkali feldspars in the ceramic samples are restricted to ceramics from Caddoan sites in the Sulphur River drainage (Reese-Taylor 1995). There, alkali feldspars are present in frequencies ranging from 0-20 percent (Figure 1). The exception to the pattern is seen in one ceramic sample from the Sabine River sites, where alkali feldspars are present at a frequency of 40 percent (Reese-Taylor 1994a). This single example of a sherd with graywacke sand in the paste in a region where no alkai feldspars are found in all the other ceramics in the sample strongly suggests the sherd is from a vessel imported into the Sabine River drainage.

Within the Sulphur River drainage, the presence of alkali feldspars is clustered by sites in most cases (Figure 2). Two types of sources are indicated: a mature quartz sand with frequencies of alkali feldspars in the paste of less than 10 percent (sites 41TT392, 41TT396, and 41TT409), and a more immature arkosic sand with higher (between 12-16 percent) alkali feldspar frequencies (in ceramics from sites 41TT399 and 41TT406). Two sites show a range of frequencies that suggest both quartz and arkosic sand sources (sce Figure 2). This difference may indicate trade of vessels within sites in the Piney Creek or Sulphur River drainages, or that two distinct sand sources were being used for procurement. At this time, the analyzed ceramic sample is too small to be conclusive; no temporal distinctions were noted that would account for the differences in alkali feldspar frequencies.

Hematite and mica are also indicators of variation in naturally occurring inclusions found within clays, or as part of some sands. Hematite was found in ceramic samples from all three drainage basins (Figure 3). Ceramics from the Sabine River drainage contain hematite in frequencies ranging from 0-32 percent, with a majority of the sherds containing frequencies above 10 percent (Reese-Taylor 1994a). In addition, mica was only present in 


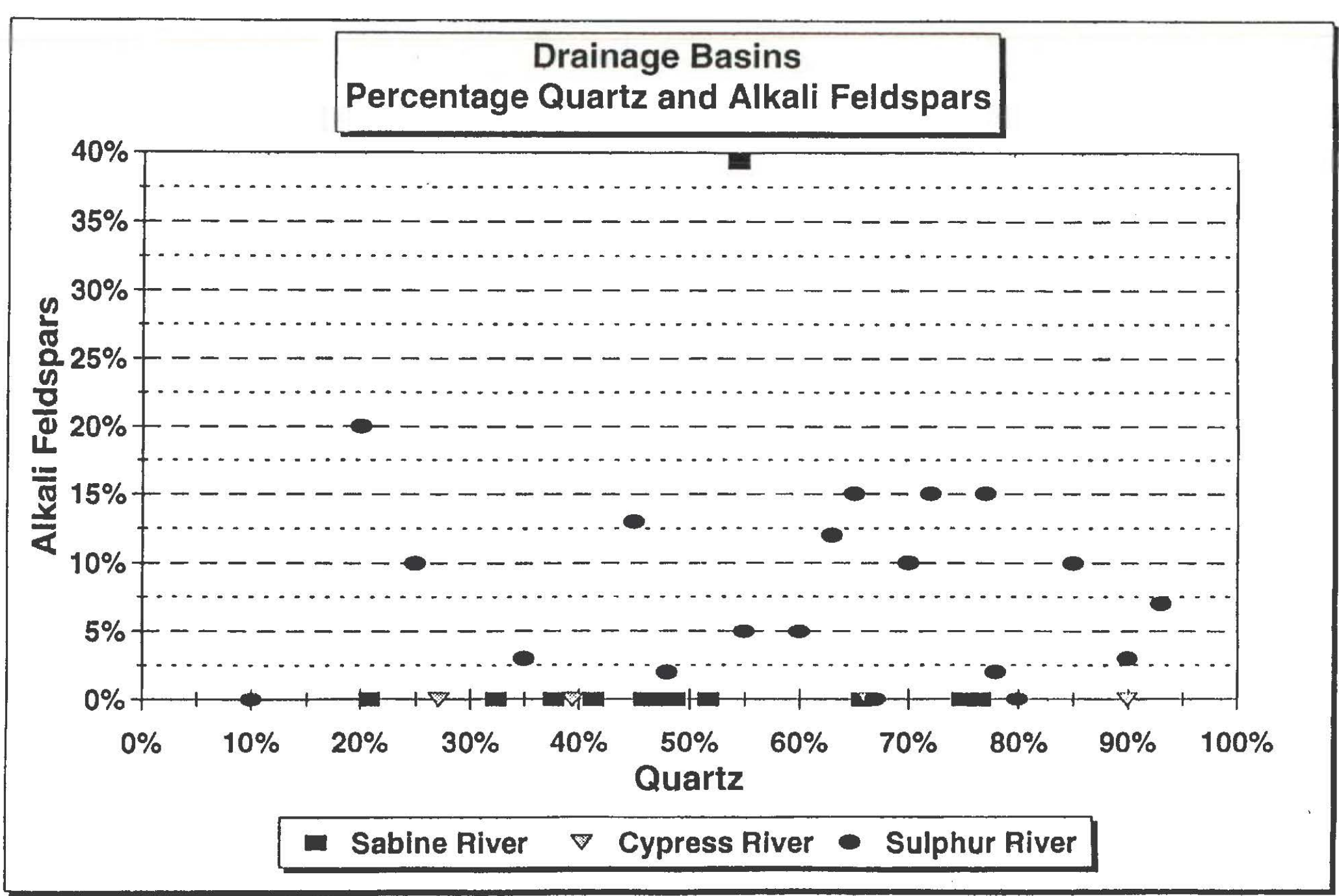




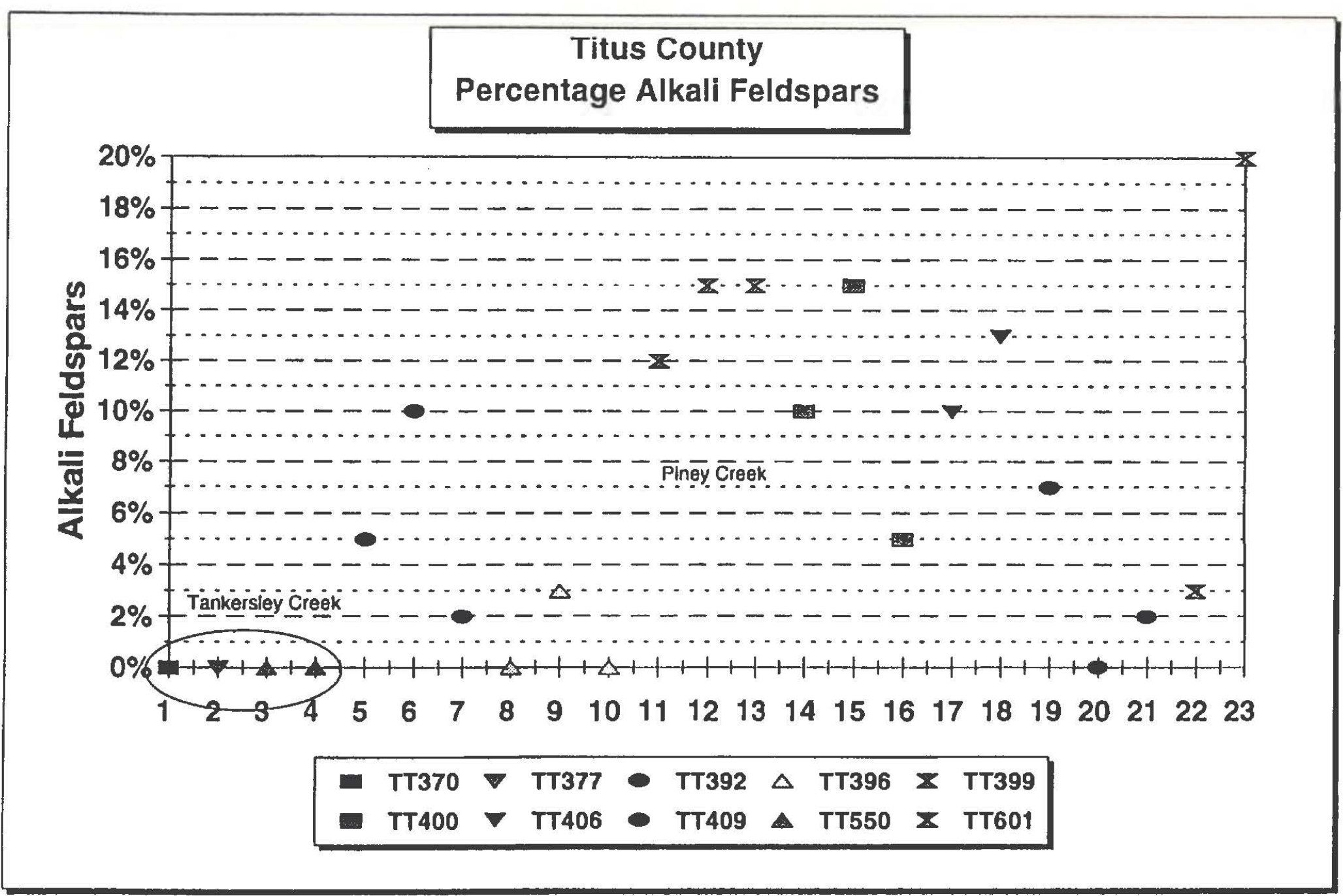




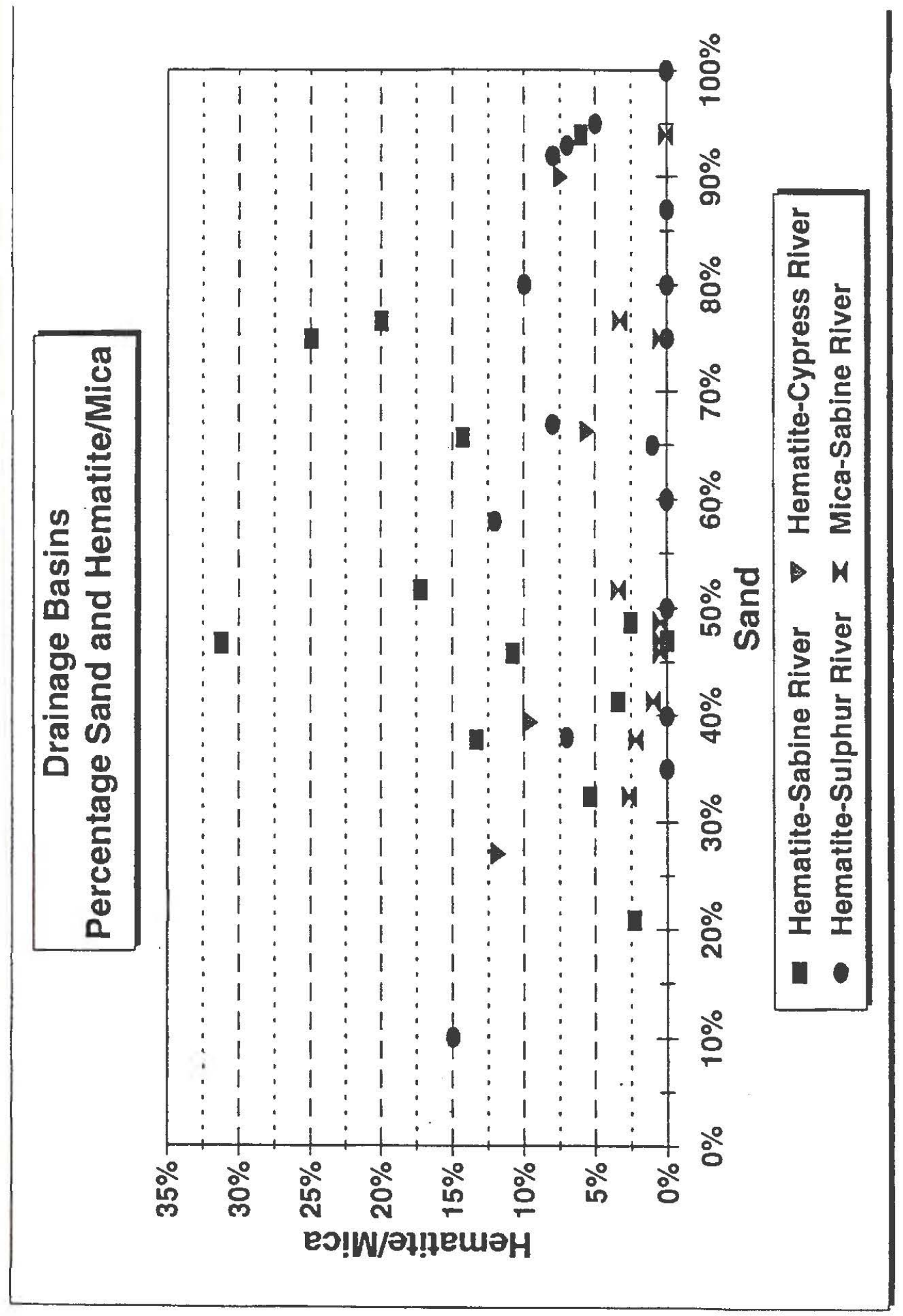

Figure 3. The Percentage of Sand and Hematite/Mica in Ceramics from the Sabine, Cypress, and Sulphur drainage basins. 
ceramic samples from the Sabine River drainage (Reese-Taylor 1994a). Samples from the Cypress Creek drainage contain hematite in a more restricted and lower range (6-12 percent) than that found in the Sabine River ceramics (Reese-Taylor 1993). Ceramic samples from the Sulphur River drainage have hematite in still lower frequencies, ranging from 0-15 percent, but the majority of the ceramics contain less than 10 percent hematite in the paste. Once again in the Sulphur River drainage, the range of hematite in the Caddoan ceramics clusters according to site, although most sites contain less than 10 percent hematite in the paste (Figure 4). However, anomalies in hematite frequencies show up in samples from 41TT406 and 41TT409. The variation seen in hematite and alkali feldspar in 41TT406 ceramics strongly suggests two very distinct procurement locales for the sands and/or clays, and argues for some ceramics being traded into the region from another locale (Reese-Taylor 1994b).

\section{• Manufacturing Techniques}

.. Bone tempering occurs in the ceramics from both the Sabine and Sulphur River drainage basins. As a percentage of the total non-plastics added to the paste, bone appears in a greater range of frequencies in the Sabine River drainage ccramics (Figure 5). Specifically, when bone is present, it ranges from 18-43 percent, and in greater proportions relative to sand inclusions (Reese-Taylor 1994a). Alternatively, in the Sulphur River drainage, the percentage of bone inclusions ranges between 15-35 percent, and it occurs in lower proportions relative to sand inclusions (Reese-Taylor 1995). Because sand occurs in approximately equivalent frequency ranges in the ceramics from both river drainages, I have interpreted this to mean that the Caddo potters in the Sabine River drainage were intentionally using fewer sand inclusions (or less sandy paste) and greater amounts of bone inclusions when making this kind of ceramic paste than their counterparts in the Sulphur River basin (Reese-Taylor 1994b). 


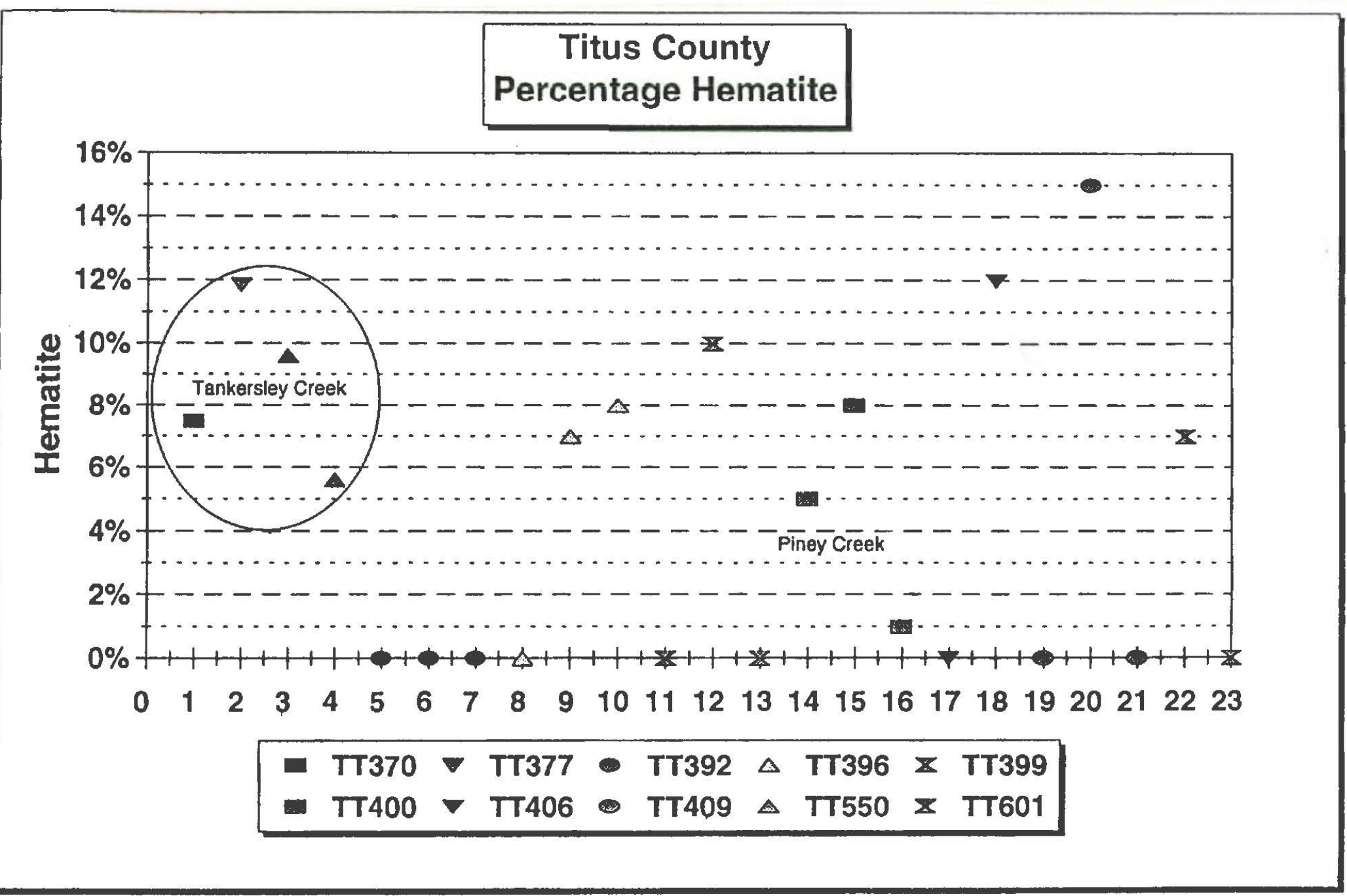




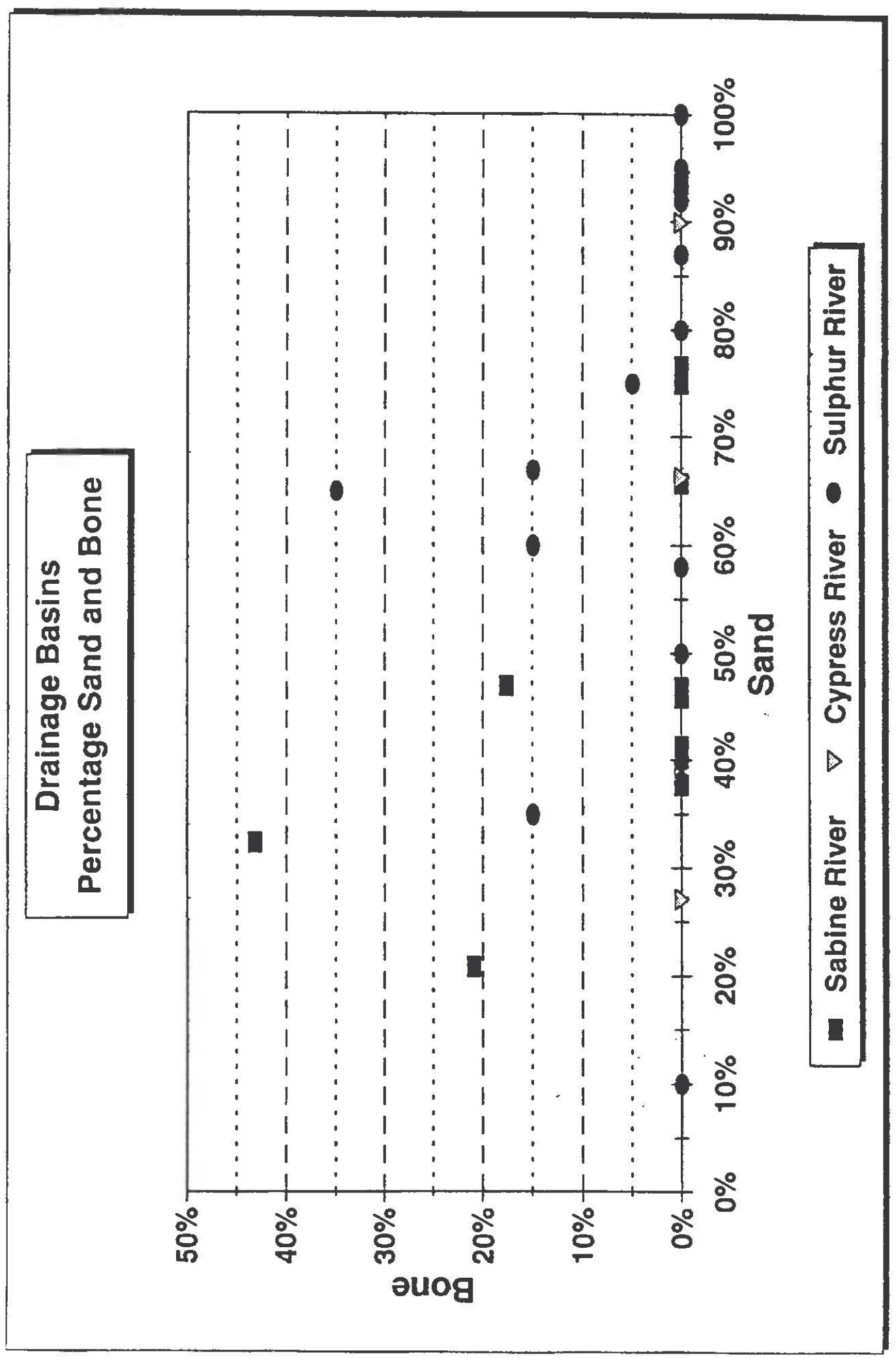

Figure 5. The Percentage of Sand and Bone in Ceramic Samples from the Sabine, Cypress, and Sulphur drainage basins. 
Similarly with grog tempering, a distinction can be seen in the proportions of grog and sand among the drainage basins (Figure 6). In the Sabine River drainage, grog is used in higher proportions in the ceramics with less amounts of sand, and in the Sulphur River drainage, grog is used in the paste in similarly high proportions with more sand (ReeseTaylor 1994a, 1995). The Cypress Creek drainage ceramics demonstrate a comparable pattern to that found in the Sulphur River drainage (Reese-Taylor 1993). Interestingly, ceramic samples from the Sulphur River drainage show a negative correlation between grog and sand, with the use of grog decreasing as the frequency of sand in the paste increases. This is not the pattern observed in the Caddoan ceramic samples from the Sabine River drainage. There, where grog is present, it consistently appears at levels between 25-55 percent, while sand occurs at levels between 20-50 percent (Reese-Taylor 1994b).

The river drainage basin differences noted between the proportions of bone and grog in the Caddoan ceramics in relationship to the use of sand represent different manufacturing traditions of the Caddoan peoples living in these locales. At this time, there is no evidence for temporal distinctions in the use of grog, bone, or sand, while from the ceramic data presented above there is stronger support for these differences relating to the existence of regional production traditions. However, further sampling of ceramics from different Caddoan periods may provide a stronger argument for changes in manufacturing through time.

\section{Manufacturing/Function}

The measure of porosity and the type and size of non-plastics within a ceramic vessel often suggests functional correlates. In the present Caddoan ceramic samples, ceramic function may not be conclusively determined, but the comparison between relative porosity and the percentage of non-plastics can again be indicative of differences in production techniques. 


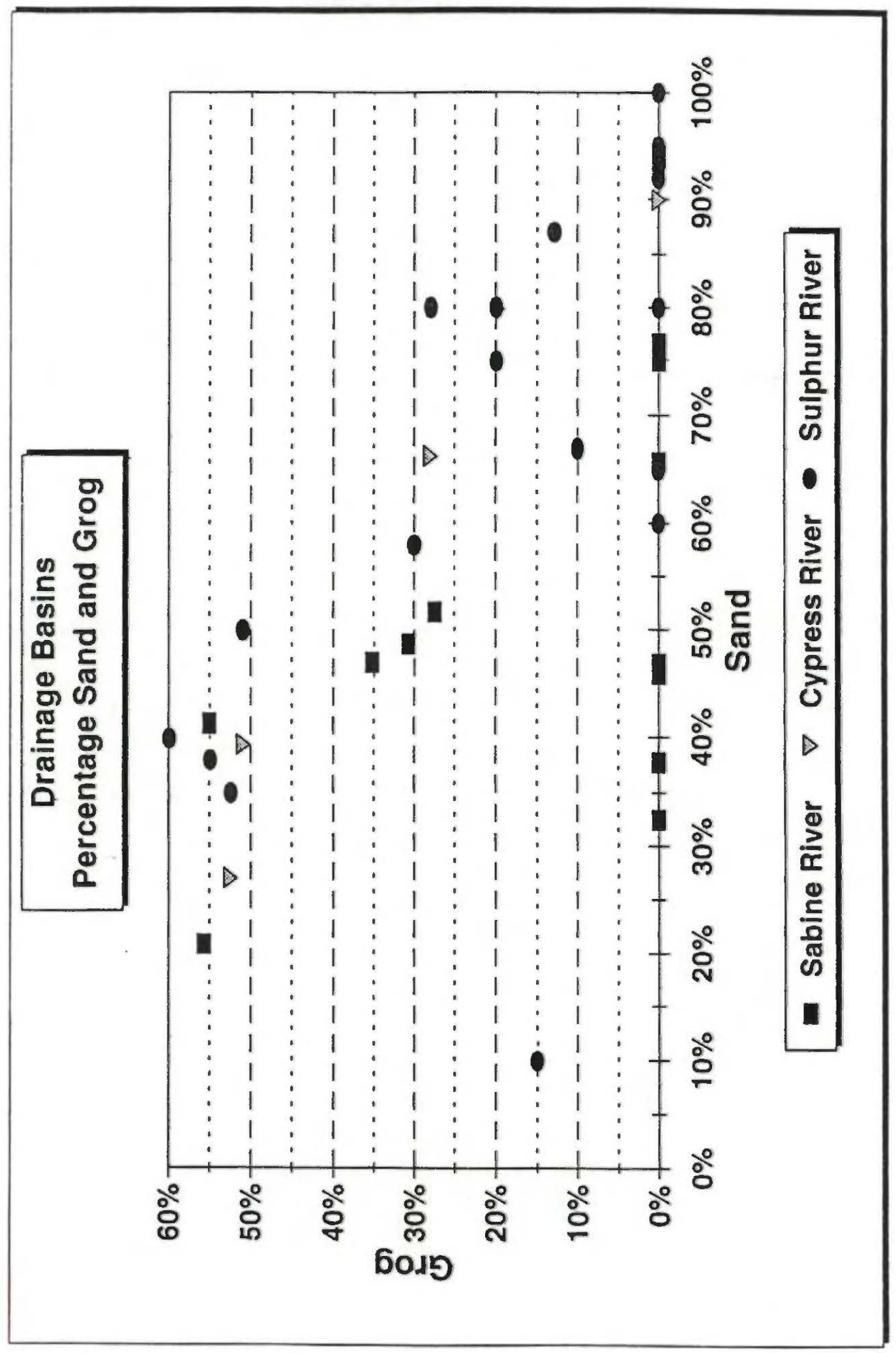

Figure 6. The percentages of sand and grog in Sabine River, Cypress Creek, and Sulphur River Ceramic samples. 
In a majority of the ceramic samples, porosity ranges between 4-10 percent, while the percentage of non-plastics falls between 20-50 percent (Figure 7). This suggests the existence of an overarching model for ceramic production shared by all Caddoan potters within the study area.

Specifically, however, grog-tempered pastes show a higher porosity (10-16 percent) than the other kinds of paste/temper combinations, with ceramic samples from the Sulphur River basin having generally more pores than those from the Sabine River drainage basin (see Figure 7). Bone and shell-tempered ceramics from the Sulphur River basin also have a much higher frequency of pores than bone-tempered sherds from the Sabine River basin. Grog temper, along with bone and shell, as well as large pores, are superior thermal conductors (Rice 1987). Therefore, grog, bone, and shell temper, along with large or frequent pores, would produce more efficient cooking vesscls. This implies that the manufacturing techniques used by the Caddo to produce ccramic vessels in the Sabine and Sulphur river basins may have produced a varying effectiveness in function as well (cf. Rice 1987). In other words, if the Caddo's goal was to produce a ceramic vessel that cooked quickly and efficiently, a grog- or bone-tempered vessel from the Sulphur River drainage would have been superior to those bcing made in the Sabine River drainage basin.

\section{SUMMARY}

In summary, four main points can be reiterated:

1. The frequency of clay matrix, pores, and non-plastics suggest an overarching model for ceramic production shared by all Caddoan potters in the region.

2. Gencral frequencies of alkali feldspars, hematite, and mica in the paste of the ceramic samples suggests the localized production for most of the Caddoan ceramics, but frequency anomalics in these inclusions indicate that 


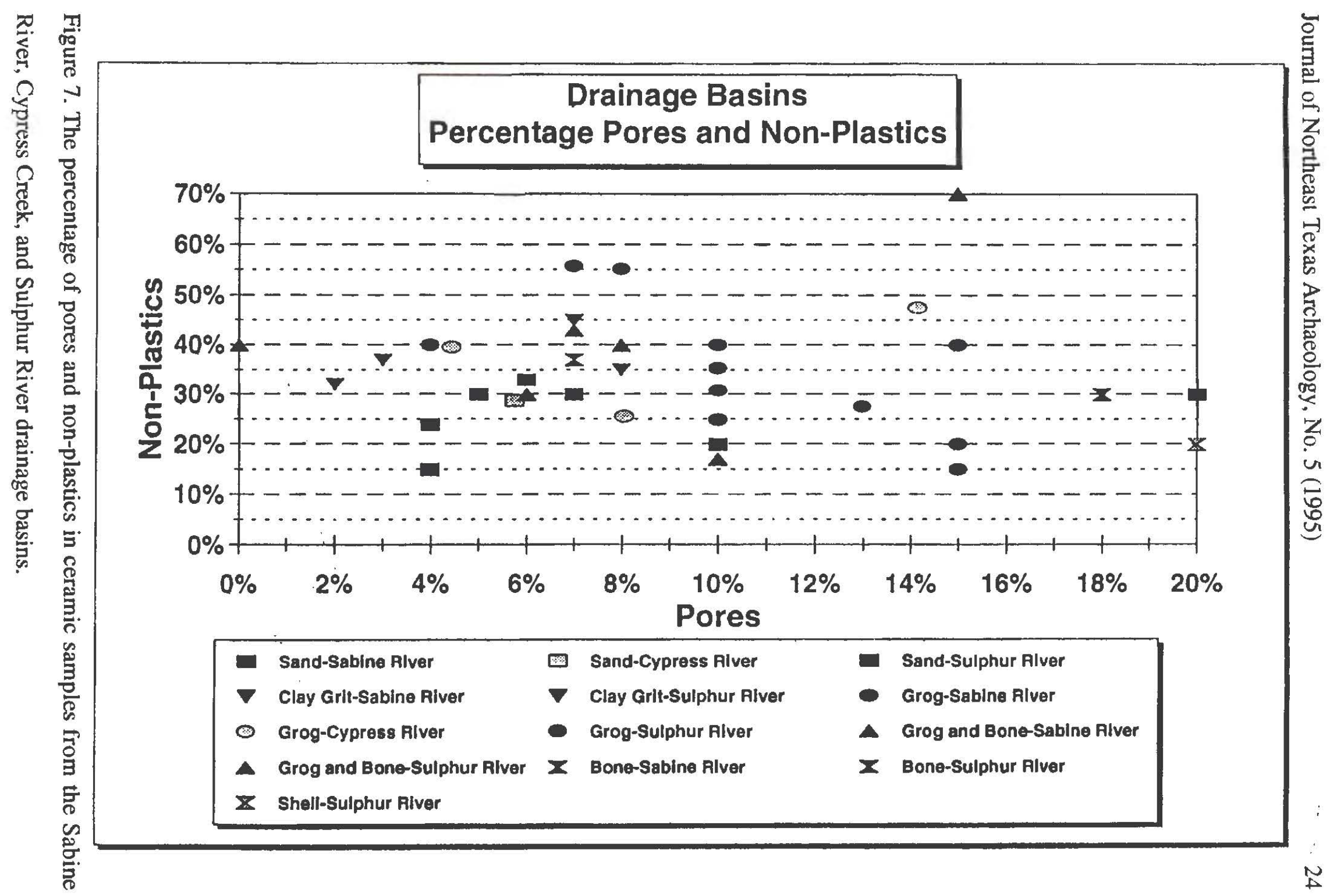


ceramics were traded between groups in the Sabine and Sulphur river drainage basins.

3. The frequency of bone and grog temper in relationship to sand suggests that slightly different manufacturing techniques were used by Caddoan groups in the Sabine and Sulphur river drainage basins.

4. Differences in the relative porosity of grog, bone, and shell-tempered sherds from the different river drainages indicate not only manufacturing differences, but differences in functional effectiveness.

No temporal distinctions were noted to account for differences in the procurement and manufacturing patterns summarized above. However, as morc ceramic thin-sections are analyzed from these regions, we expect to discern differences through time in Caddoan ceramic procurement and manufacturing.

\section{ACKNOWLEDGMENTS}

I would like to thank Texas Utility Scrvices and Espey, Huston \& Associates, Inc. for the opportunity to work on the collection. This research was also supported by an Advanced Research Projects Grant through the Department of Anthropology, University of Texas at Austin, administered by Dr. Thomas Hester.

\section{REFERENCES}

Cruse, J. B.

1995 Archaeology at the Oak Hill Village Site: A Caddoan Settlement in Rusk County. Heritage 13(1):10-14. Texas Historical Foundation, Austin.

Folk, D.

1968 Petrology of Sedimentary Rocks. Hemphill Publishing Company, Austin. 
Kotter, S. M., R. Rogers, R. Taylor, K. Reese-Taylor, and W. P. Glander

1993 Archaeological Investigations within the Monticello B-2 First Five-Year Disturbance Area, Titus County, Texas. Document No. 920013. Espey, Huston \& Associates, Inc., Austin.

Nash, M. A., S. M. Kotter, and K. V. Reese-Taylor

1995 National Register Testing of Ten Sites in the Monticello B-2 Surface Mine, Titus County, Texas. Document No. 930529. Espey, Huston \& Associates, Inc., Austin.

Reese, K. V.

1989 The Ceramics of Kichpanha. Unpublished M.A. thesis, Texas A\&M University, College Station.

Recse-Taylor, K.

1993 Petrographic Analysis of Caddo Ceramics from Titus County, Northeast Texas. In Archaeological Investigations within the Monticello B-2 First Five-Year Disturbance Area, Titus County, Texas, by S. M. Kotter, R. Rogers, R. Taylor, K. Reese-Taylor, and W. P. Glander, pp. A-1 to A-13. Document No. 920013. Espey, Huston \& Associates, Inc., Austin.

Reese-Taylor, $\mathrm{K}$.

1994a Petrographic Analysis of Caddoan Ccramics from Rusk County, Texas. In National Register Testing at Eight Archaeological Sites within the Oak Hill 2,280-Acre Study Area, Rusk County, Texas, by R. Rogers, E. Foster, and K. Reese-Taylor, pp. B1 to B-15. Document No. 930169. Espey, Huston \& Associates, Inc., Austin.

1994b Ceramic Production and Consumption Patterns in Early, Middle, and Late Caddoan Settlements from Rusk and Titus Counties, Texas. Paper presented at the 65 th Annual Mecting of the Texas Archeological Society, November 4-6, Lubbock, Texas. 
Reese-Taylor, K.

1995 Petrographic Analysis of Ceramics. In National Register Testing of Ten Sites in the Monticello B-2 Surface Mine, by M. A. Nash, S. M. Kotter, and K. V. ReeseTaylor, pp. C-1 to C-13. Document No. 930529. Espey, Huston \& Associates, Inc., Austin.

Rice, P. M.

1987 Pottery Analysis: A Sourcebook. University of Chicago Press, Chicago.

Rogers, R., E. Foster, and K. Reese-Taylor

1994 National Register Testing at Eight Archaeological Sites within the Oak Hill 2,280Acre Study Area, Rusk County, Texas. Document No. 930169. Espey, Huston \& Associates, Inc., Austin.

Shepard, A. O.

1976 Ceramics for the Archaeologist. Publication 609. Carnegie Institution of Washington, Washington, D.C. 